\title{
EFFECTS OF CLIMATIC CONDITIONS, HOUSING SYSTEM AND BREED ON PERFORMANCE OF MATURE RABBIT BUCKS RAISED IN MIDDLE EGYPT
}

\author{
Samia Z. Meshreky, S.A.Z. Gad Alla and M.A. Abo-Warda \\ Animal Production Research Institute, Agricultural Research Center, Giza, Egypt
}

\section{SUMMARY}

Forty-four New Zealand White (NZW) and Baladi black (BB) rabbit bucks of 8 months old were used in this study during two climate conditions. Twelve NZW and $10 \mathrm{BB}$ rabbits were used in hot climatic conditions (May-October 2003) and $12 \mathrm{NZW}$ and $10 \mathrm{BB}$ rabbits were used in mild climatic conditions (November-April 2004), respectively. In each period, bucks in each breed were divided into two equal groups according to the housing system. The first group was raised in semi-closed rabbitry and the second was housed in an open rabbitry under shed. The estimated temperature-humidity index values indicated that exposure of rabbits to very severe heat stress under semi-closed building while those raised under shed were exposed to moderate heat stress during the hot period and absence of heat stress in the mildclimate period.

Thermoregulatory and hematological response, plasma testosterone concentrations, sexual behavior, semen characteristics and fertilizing ability were $(P<0.001,0.01$ or 0.05$)$ adversely affected by semi-closed housing system and hot climate period. During mild climate period, NZW bucks raised in semi-closed system showed the best thermoregulatory and hematological responses, and values of testosterone concentration and consequently best semen quality, fertilizing ability and litter size at birth, followed by those housed in open system than BB rabbit bucks. Hot climatic condition period adversely affected performance of NZW bucks raised in the semi-closed system than that of BB rabbits, however, housing NZW bucks in the open system during hot period alleviated heat stress and improved their performance. These results showed the superiority of the open system during hot climate period, since physical properties of building materials and environmental conditions under shed are markedly reflected on the bucks performance as indicated by both physiological reactions and biological responses which are the most and accurate indicators for rabbits welfare.

Keywords: Climatic conditions, housing system, breed, rabbit bucks, thermoregulatory parameters, semen quality

\section{INTRODUCTION}

Reproductive success, defined by fertility and litter size, greatly determines the efficiency of meat rabbit production. Failures in fertilization or embryogenesis have been shown to be in part of semen origin (Saacke et al., 2000). High quality semen

Issued by The Egyptian Society of Animal Production 
are required year-round to achieve the maximum number of suitable doses for insemination. Environmental, physiological and genetic factors can affect normal spermatogenesis as well as sperm function, thereby altering male fertility. Concerning environment, thermal stress implies a deregulation in the thermal neutral zone of the animals, which could lead to changes in biological functions of animals, so a "seasonal sterility" has been described in several mammalian species, in which high ambient temperatures could affect levels of testosterone and reproductive functionality of rabbit males (Alvariño, 2000 and Meshreky, 2007). Rabbit's production demands great quantity of labors, to create an adequate environment in relation with both hygiene and comfort that allows them better performance on each physiological stage (Villalobos et al., 2008).

Hot months in the middle Egypt are a very long time, which starts from April and continues till October. Rabbits in hot conditions are very susceptible to heat stress and suffering from eliminating excess body heat. Physical stressors include environmental variables such as housing system and climatic factors (Verga et al., 2007). Therefore, applying the sanitary methods and adopting the modern experience in the field of raising rabbits and prevention from diseases are essentials for successful rabbit production.

Housing systems for rabbits should be efficient in environmental control to insure better biological performance and good economic return. Poor building design and unsuitable microclimates can result in stresses on the rabbit stock, with consequent lower reproductive efficiency and loss in production (Baumans, 2005). The main welfare indicators to assess rabbit housing are mortality (unavoidable low), morbidity (unavoidable low), physiological parameters in the species-specific standard, species-specific behavior and performance on a high level (Hoy, 2008). The housing of rabbits is must be related to behavioural, hygienic, environmental and welfare aspects. Although a high performance is no proof of a high welfare level, a low performance is an indicator of problems in housing, environment and management.

The aim of this study was to investigate the effect of housing system under both hot and mild climatic conditions of middle Egypt on physiological responses and its reflection on reproductive performance of New Zealand White and Baladi Black rabbit bucks.

\section{MATERIALS AND METHODS}

The present study was carried out in the rabbitry at Seds Research Station, BeniSuef Governorate, Animal Production Research Institute, Agricultural Research Center, Ministry of Agriculture. Forty-four New Zealand White (NZW) and Baladi black (BB) rabbit bucks of 8 months old were used in this study during two climate conditions. Twelve NZW and $10 \mathrm{BB}$ rabbits were used in hot climatic conditions (May-October 2003) and $12 \mathrm{NZW}$ and $10 \mathrm{BB}$ rabbits were used in mild climatic conditions (November-April, 2004), respectively. In each period, bucks in each breed were divided into two equal groups according to the housing system.

The first group of animals was housed in semi-closed rabbitry building of $12 \mathrm{~m}$ length, $5 \mathrm{~m}$ width and $3.5 \mathrm{~m}$ height with wire netted windows at the east side for providing natural ventilation. The windows height was $0.9 \mathrm{~m}$ from the floor. Three doors of $2 \mathrm{~m}$ high $\times 0.9 \mathrm{~m}$ width are present at the west side of the rabbitry. Roofed by $15 \mathrm{~cm}$ thick reinforced concrete slab. The walls are made of $12 \mathrm{~cm}$ thick common 
brick and $2 \mathrm{~cm}$ plaster, inside and outside of the wall. The floor of the rabbitry was made of concrete. Rabbits were kept individually in galvanized wire cages (45 x $60 \mathrm{x}$ $35 \mathrm{~cm}$ ) and arranged in double tier batteries supplied with feeding hoppers and nipples for automatic drinking. The second group of animals was housed in open rabbitry system, under shed made of corrugated iron sheet of $6 \mathrm{~m}$ height, surround by a wall of $3 \mathrm{~m}$ height and some of gazwarina trees of 8-11 $\mathrm{m}$ height behind the wall. Rabbits were kept individually in cement pen $(85 \times 60 \times 60 \mathrm{~cm})$. The pens unit was built in two floors $0.6 \mathrm{~m}$ above the ground; each of 8 pens and supplied with feeding hoppers and nipples for automatic drinking. The floor and the door of the pen were made of galvanized wire net. The pens units were built in parallel lines with $1.2 \mathrm{~m}$ inbetween, each of the east side and another of the west side. The floor of the rabbitry was made of cement.

Air temperature $\left({ }^{\circ} \mathrm{C}\right)$ and relative humidity (\%) inside the semi-closed rabbitry building or under shed were measured weekly throughout the experimental periods between 12.00 to $14.00 \mathrm{~h}$ using automatic thermo-hygrometer. Averages of air temperature and relative humidity values at mid-day inside the semi-closed rabbitry building and under shed were $37.4 \pm 0.6^{\circ} \mathrm{C}, 71.1 \pm 3.2 \%, 30.1 \pm 0.6^{\circ} \mathrm{C}, 65.3 \pm 2.8 \%$ during the hot period and $24.4 \pm 0.7^{\circ} \mathrm{C}, 69.2 \pm 2.1 \%, 21.9 \pm 0.7^{\circ} \mathrm{C}$ and $62.2 \pm 2.1 \%$ during the mild period, respectively. The temperature-humidity index (THI) was calculated using the equation proposed by Marai et al. (2002) as follows: $\mathrm{THI}=\mathrm{db}^{\circ} \mathrm{C}-[(0.31-$ $\left.0.31 \mathrm{RH})\left(\mathrm{db}^{\circ} \mathrm{C}-14.4\right)\right]$, where $\mathrm{db}^{\circ} \mathrm{C}=$ dry bulb temperature in celsius and $\mathrm{RH}=$ relative humidity percentage/100. The THI values obtained were then classified as follows: $<27.8=$ absence of heat stress, $27.8-<28.9=$ moderate heat stress, 28.9$<30.0=$ severe heat stress and 30.0 and more $=$ very severe heat stress.

The bucks in all groups were offered feed and water ad libitum. The chemical analysis of the commercial pelleted diet was $16.5 \%$ crude protein, $14.1 \%$ crude fibre, $2.9 \%$ Ether extract and $2650 \mathrm{kcal} \mathrm{DE} / \mathrm{kg}$ diet digestible energy. Rectal temperature was measured individually at midday biweekly by a digital thermometer (3-4 $\mathrm{cm}$ of rectum), during the two experimental periods. Respiration rate was measured at midday biweekly by visually counting breaths per minute using a stop watch. Three blood samples from the marginal ear vein of rabbit bucks in each breed of each housing system during the two periods of the year were taken randomly biweekly in heparinized centrifugation tubes to determine hemoglobin, hematocrit, and testosterone hormone concentrations in plasma using commercial diagnostic kits.

Semen was collected (using artificial vagina) weekly from each buck in each of two housing and breed during the two experimental periods. The samples were kept into a water bath at $37^{\circ} \mathrm{C}$ for evaluation. Sexual behavior (reaction time, RT) was measured, which was the time interval from the introduction of the teaser doe into the male's cage to ejaculation. It was measured in seconds using a stopwatch. Semen quality was evaluated by ejaculate volume, sperm motility percentage, sperm cell concentration, and percentages of dead and abnormal sperm. The gel mass was removed from semen samples before examination. Bucks were mated naturally with mature does from the same breed to obtain fertilizing ability of bucks (number of conceptive does/ number of mated does x100) and litter size at birth.

Data were statistically analyzed using General Linear Model procedure of SAS ${ }^{\circledR}$ Program (1996) according to the following model: 
$\mathrm{Y}_{\mathrm{ijk} \ldots}=\mu+\mathrm{C}_{\mathrm{i}}+\mathrm{H}_{\mathrm{j}}+\mathrm{B}_{\mathrm{K}}+$ all interaction available $+\mathrm{e}_{\mathrm{ijk} \ldots . .}$, Where $\mathrm{Y}_{\mathrm{ijk} \ldots}=$ The observation, $\mu=$ General mean, $C_{i}=$ Fixed effect of $i^{\text {th }}$ climatic conditions $(i=1,2 ; 1$, hot conditions and 2 , mild conditions), $H_{j}=$ Fixed effect of $j^{\text {th }}$ housing system, $j=1$ (semi-closed) and 2 (open system), $\mathrm{B}_{\mathrm{k}}=$ the fixed effect of $\mathrm{k}^{\text {th }}$ breed, $\mathrm{k}=\mathrm{NZW}$ and $\mathrm{BB}$, and $\mathrm{e}_{\mathrm{ijk} . .}=$ Error of the model. Significance of the differences in the results was tested by Duncan's New Multiple Range Test (Duncan, 1955). Data in percentage were transformed with the arcsine square-root procedure to normalize variance before analysis.

\section{RESULTS AND DISCUSSION}

The estimated THI values were 35.34 and 28.41 during the hot climate and 23.45 and 21.02 during the mild climate periods inside the semi-closed building and under the shed, respectively. These values indicating exposure of rabbits raised in semiclosed building to very severe heat stress and those raised under shed to moderate heat stress during the first period (hot period) and absence of heat stress in the second one (mild period). Theses results agreed with those finding by García-Tomas et al. (2008b) who found that the comfort zone temperature of rabbits is around $21^{\circ} \mathrm{C}$ and that their productive and reproductive performance could be impaired when temperature-humidity index (THI) is over 27.8, value that implies the beginning of heat stress. Marai et al. (2002) also, reported that when exposed to THI 30 or more, rabbits can no longer regulate internal temperature and heat prostration sets in.

\section{Effect of climatic conditions:}

All studied traits of thermoregulatory and hematological responses, testosterone hormone levels, sexual behavior (reaction time), semen characteristics, fertilizing ability percentage and litter size at birth were significantly $(\mathrm{P}<0.001,0.01$ or 0.05$)$ affected by temperature-humidity interaction during two climatic condition periods studied (Table 1).

Rectal temperature (RT) and respiration rate (RR) were higher with increasing temperature-humidity value during hot condition; whereas hematocrit (Ht) percentage and hemoglobin $(\mathrm{Hb})$ concentration were lower during hot condition than that during mild condition. This may be due to the failure of the physiological mechanisms to maintain the thermal balance of the animal (Abdel Samee et al., 2005). In addition, several investigators found that respiration rate increased under heat stress conditions (Meshreky 2007 and Ogunjimi, 2007). Lebas et al. (1997) also, showed that when ambient temperature increased the animal pants to enhance heat loss throughout water evaporation.

During hot climatic condition, plasma testosterone concentrations were lower by $18.11 \%$ than that during mild condition (Table 1). The reduction in testosterone level during summer resulted from reducing the ability of leydig and sertoli cells responding to LH hormone (Jegou et al., 1984). In addition, increase temperaturehumidity values during hot period suppressing sexual behavior (reaction time), semen characteristics, fertilizing ability and litter size at birth (Table 1). The negative effects of heat stress during hot period on traits studied are consistent with the findings of Marai et al. (2004); Pascual et al. (2004); Ashour et al. (2005); and Meshreky et al. (2005). 
Table 1. Thermoregulatory and hematological responses, testosterone hormone concentration, sexual behavior (reaction time), semen characteristics and fertilizing ability of rabbits as affected by climatic conditions and housing system

\begin{tabular}{|c|c|c|c|c|c|c|}
\hline \multirow{2}{*}{ Items } & \multicolumn{2}{|c|}{ Climatic conditions } & \multirow{2}{*}{ - Sig. } & \multicolumn{2}{|c|}{ Housing systems } & \multirow{2}{*}{-Sig. } \\
\hline & Hot & Mild & & Semi-closed & Open & \\
\hline \multicolumn{7}{|c|}{ Thermoregulatory responses: } \\
\hline Rectal temperature $\left({ }^{\circ} \mathrm{C}\right)$ & $40.94 \pm 0.11$ & $39.57 \pm 0.11$ & $* *$ & $40.43 \pm 0.11$ & $40.08 \pm 0.11$ & $*$ \\
\hline Respiration rate & $139.6 \pm 1.9$ & $102.5 \pm 1.9$ & $* * *$ & $129.9 \pm 1.9$ & $112.2 \pm 1.9$ & $* *$ \\
\hline \multicolumn{7}{|l|}{ Hematological responses: } \\
\hline Hematocrit (Ht, \%) & $32.79 \pm 0.33$ & $39.12 \pm 0.33$ & $* * *$ & $34.91 \pm 0.33$ & $36.99 \pm 0.33$ & $* *$ \\
\hline Hemoglobin $(\mathrm{Hb}, \mathrm{g} / \mathrm{dl})$ & $11.04 \pm 0.13$ & $13.06 \pm 0.13$ & $* *$ & $11.62 \pm 0.13$ & $12.48 \pm 0.13$ & $* *$ \\
\hline $\begin{array}{l}\text { Testosterone hormones } \\
(\mathrm{ng} / \mathrm{ml})\end{array}$ & $1.99 \pm 0.05$ & $2.43 \pm 0.05$ & $* * *$ & $2.15 \pm 0.05$ & $2.27 \pm 0.05$ & NS \\
\hline Reaction time (second) & $27.98 \pm 0.45$ & $21.21 \pm 0.45$ & $* * *$ & $28.17 \pm 0.45$ & $21.03 \pm 0.45$ & $* * *$ \\
\hline \multicolumn{7}{|l|}{ Semen characteristics: } \\
\hline Ejaculate volume (ml) & $0.598 \pm 0.01$ & $0.643 \pm 0.01$ & $* *$ & $0.628 \pm 0.01$ & $0.613 \pm 0.01$ & NS \\
\hline $\begin{array}{l}\text { Sperm Concentration } \\
\left(\mathrm{x} 10^{6} / \mathrm{ml}\right)\end{array}$ & $303.19 \pm 4.3$ & $337.13 \pm 4.3$ & $* *$ & $304.75 \pm 4.3$ & $335.56 \pm 4.3$ & $* *$ \\
\hline Sperm motility (\%) & $61.42 \pm 0.44$ & $81.04 \pm 0.44$ & $* * *$ & $69.07 \pm 0.44$ & $73.38 \pm 0.44$ & $* *$ \\
\hline Dead sperm $(\%)$ & $28.44 \pm 0.37$ & $17.60 \pm 0.37$ & $* * *$ & $26.11 \pm 0.37$ & $19.93 \pm 0.37$ & $* *$ \\
\hline Sperm abnormality (\%) & $24.82 \pm 0.47$ & $16.22 \pm 0.47$ & $* *$ & $21.58 \pm 0.47$ & $19.47 \pm 0.47$ & $*$ \\
\hline \multicolumn{7}{|c|}{ Fertilizing ability (\%): } \\
\hline $\begin{array}{l}\text { No. concept/No. } \\
\text { insemination }\end{array}$ & $\begin{array}{c}161 / 264 \\
(61.69)\end{array}$ & $\begin{array}{c}220 / 293 \\
(75.09)\end{array}$ & $*$ & $\begin{array}{c}191 / 279 \\
(68.46)\end{array}$ & $\begin{array}{c}190 / 275 \\
(69.09)\end{array}$ & NS \\
\hline Litter size at birth & $5.72 \pm 0.13$ & $6.49 \pm 0.11$ & $* * *$ & $5.99 \pm 0.11$ & $6.23 \pm 0.11$ & \\
\hline
\end{tabular}

Sig.= Significance.

a,b Values with different superscripts in the same row, differ significantly $(\mathrm{P}<0.05)$.

${ }^{* * *} \mathrm{P}<0.001,{ }^{* *} \mathrm{P}<0.01,{ }^{*} \mathrm{P}<0.05$ and NS $=$ not significant.

Sperm cell concentration $\left(\times 10^{6} / \mathrm{ml}\right)$ and sperm motility were decreased with increasing temperature-humidity value during hot period than mild period, while dead sperm and sperm abnormalities percentages tended to increase (Table 1). These results were in agreement with those reported by Roca et al. (2005) who showed that the acute exposure to high THI (30) had immediate negative effects on sperm concentration, total number of spermatozoa per ejaculate, sperm motility and sperm normalcy. The values of these traits showed a great drop two weeks later of the highest THI, but this variable remained practically constant when THI ranged between 15 and 20. Rodríguez-De Lara et al. (2008) found that season determined differences $(\mathrm{P} \leq 0.05)$ in all semen analyzed variables except for volume that was similar in both seasons (winter and spring).

The decrease of semen volume in hot period may be due to low sperm concentration and/or a decrease in the volume of seminal plasma (Tharwat et al., 2004). Hammond et al. (1983) reported that, the low ejaculate volume in summer may be due to hypo activity of the accessory sexual glands and testes as a response to the high ambient temperature. Moreover, El-Sherry et al. (1980) found that the decrease in sperm cell concentration may be due to degeneration of germinal epithelium and partial atrophy in the semniferous tubules. El-Sobhy (2000) also found that the testes of heat exposed animals revealed significant focal degeneration 
in both seminiferous tubules and interstitial cells. In addition, the influence of high ambient temperature prevailing during the summer season on spermatogenesis leading to the high percentage of deformed spermatozoa (Rathore, 1970).

The reduction in fertilizing ability and litter size at birth under hot climatic condition may be due to the adversely effect of heat stress fertility (Pla, 1998). Moreover, Theau-Clement et al. (1995) observed that environment plays an important role in the regulation of reproductive function, that it's stimulate must act through the nervous system and the hypothalamo- pituitary axis. In addition, Piles et al. (2008) found that sperm dosage has an important effect on male fertility.

\section{Effect of housing system:}

In spite of climatic conditions, all studied traits of thermoregulatory and hematological responses, sexual behavior, semen characteristics and litter size at birth were significantly $(\mathrm{P}<0.001,0.01$ or 0.05$)$ affected by housing system, while plasma testosterone hormone concentrations, ejaculate volume and fertilizing ability percentage insignificantly affected by housing system (Table 1).

The RT and RR were higher in rabbits raised in semi-closed building than those housed in open system, whereas $\mathrm{Ht}$ percentage and $\mathrm{Hb}$ concentrations tended to be lower. Bucks housed in open system had higher testosterone concentrations, better sexual behavior, good values of semen characteristics and litter size at birth than those housed in semi-closed system. Variations in traits studied due to housing system can be explained as a result of variations in air temperature and humidity interaction inside the two systems (Meshreky and Farid, 2007). These results are in conformity with the studies of Ashour and Shafie (2002), EL-Kholy (2003), ElBashary et al. (2005), Ibrahim et al. (2005) and Meshreky (2007).

\section{Effect of Breed:}

The only studied traits, which were not significantly affected by breed in the present study, were $\mathrm{Ht}, \mathrm{Hb}$, sperm motility and fertilizing ability percentages. However, all other traits were significantly $(\mathrm{P}<0.01$ or 0.05$)$ affected (Table 2$)$.

New Zealand White rabbit bucks had higher RT, RR, testosterone concentration, reaction time (sexual behavior), ejaculate volume, dead and abnormal spermatozoa percentages and litter size at birth than BB rabbits, except sperm cell concentration. Differences between genetic types of bucks have been found for semen characteristics and fertility. Moce et al. (2005) reported that the variability of semen characteristics in male rabbits is generally high. Also, Viudes et al. (2004) and Brun et al. (2006) observed differences in semen characteristics for males from different genetic lines and from crossbred and purebred males. These differences could be explained by differences in maternal genetic effects and the existence of heterosis for this trait (Garcia et al., 2006).

Variation between buck breeds in reaction time and semen attributes was large; this is in agreement with the findings of Theau-Clement et al. (1995) who pointed out that the cause of differences in sexual behaviour and semen characteristics could be genetic make-up. These differences between breeds may be due to the variations in pituitary gland activity, that can affect the secretion of lutilizing hormone which affects the secretion of testosterone from the interstitial tissues of testes (Al-Sobayil and Khalil, 2002). García-Tomas et al. (2007 \& 2008a) also observed differences between breeds for some morphologic traits of testis (testis size, seminiferous tubule diameter, number and size of interstitial and germ cells, etc) in developing rabbit. 
Table 2. Thermoregulatory and hematological responses, testosterone hormone concentration, sexual behavior, semen characteristics and fertilizing ability of rabbits as affected by breed.

\begin{tabular}{lccc}
\hline \multirow{2}{*}{ Items } & \multicolumn{2}{c}{ Rabbit breeds } & \multirow{2}{*}{ Sig. } \\
\cline { 2 - 3 } & New Zealand White & Baladi Black & \\
Thermoregulatory responses: & $40.69 \pm 0.10$ & $39.83 \pm 0.11$ & $* * *$ \\
Rectal temperature $\left({ }^{\circ} \mathrm{C}\right)$ & $130.71 \pm 1.9$ & $111.36 \pm 2.1$ & $* * *$ \\
Respiration rate & & & \\
Hematological responses: & $35.56 \pm 0.32$ & $36.36 \pm 0.35$ & $\mathrm{NS}$ \\
Hematocrit $(\mathrm{Ht}, \%)$ & $11.95 \pm 0.12$ & $12.15 \pm 0.14$ & $\mathrm{NS}$ \\
Hemoglobin $(\mathrm{Hb}, \mathrm{g} / \mathrm{dl})$ & $2.32 \pm 0.048$ & $2.10 \pm 0.053$ & $* *$ \\
Testosterone hormones $(\mathrm{ng} / \mathrm{ml})$ & $26.13 \pm 0.43$ & $23.07 \pm 0.43$ & $* *$ \\
Reaction time $($ second) & & & \\
Semen characteristics: & $0.689 \pm 0.009$ & $0.552 \pm 0.01$ & $* *$ \\
Ejaculate volume $(\mathrm{ml})$ & $301.56 \pm 4.1$ & $338.75 \pm 4.5$ & $* * *$ \\
Sperm concentration $\left(\mathrm{x} 10^{6} / \mathrm{ml}\right)$ & $71.29 \pm 0.42$ & $71.16 \pm 0.46$ & $\mathrm{NS}$ \\
Sperm motility $(\%)$ & $24.52 \pm 0.35$ & $21.53 \pm 0.38$ & $*$ \\
Dead sperm $(\%)$ & $21.86 \pm 0.45$ & $19.19 \pm 0.50$ & $*$ \\
Sperm abnormality $(\%)$ & $206 / 299(68.90)$ & $175 / 255(68.63)$ & $\mathrm{NS}$ \\
Fertilizing ability $(\%):$ & $6.69 \pm 0.11$ & $5.51 \pm 0.13$ & $* * *$ \\
Litter size at birth: & & & \\
\hline a,b Values with different superscripts in the same row, differ significantly $(\mathrm{P}<0.05)$. & \\
${ }^{* * *} \mathrm{P}<0.001,{ }^{* *} \mathrm{P}<0.01,{ }^{*} \mathrm{P}<0.05$ and $\mathrm{NS}=$ not significant. & &
\end{tabular}

\section{Effect of interactions:}

There were significant effects $(\mathrm{P}<0.001,0.01$ or 0.05$)$ of interaction between climatic condition and housing system, climatic condition and breed, housing system and breed, and among climatic condition, housing system and breed in some different traits studied (Tables $3,4 \& 5$ ).

In spite of rabbit breeds effect, the worst thermoregulatory and hematological responses, testosterone concentration values, sexual behavior (reaction time), semen characteristics, fertilizing ability and litter size at birth were detected in rabbits housed in semi-closed system during the hot climate period (Tables 3, 4 \& 5). Housing rabbits in open system during hot period alleviated heat stress and subsequently improved semen quality and fertility. Ogunjimi et al. (2008) found that the heat and moisture production of the rabbits significantly affected by temperature and relative humidity interaction, increased with increase of the temperaturehumidity index (THI). Hoy (2005) also concluded that low performance is an indicator for problems in housing, environment and management. In addition, Castellini (2008) reported that optimal conditions of rearing rabbit bucks can improve the spermatogenesis and the quality of semen permitting to produce additional doses with higher and more stable fertilizing ability.

During mild climatic period, NZW bucks raised in semi-closed system showed more efficient thermoregulatory and hematological responses, and $(\mathrm{P}<0.001,0.01$ or $0.05)$ values of testosterone concentration and consequently good sexual activity (reaction time), semen quality, fertilizing ability and litter size at birth, followed by those housed in open system than BB buck rabbits (Table 3, 4 \& 5). This may be due to very low temperature $\left(4^{\circ} \mathrm{C}\right)$ through night during mild period in the middle Egypt. 
The worst values of traits studied were recorded in NZW bucks housed in semiclosed system during the hot period. Results revealed that increased air temperature and humidity during hot period adversely affected performance of NZW bucks raised in the semi-closed system markedly than that of BB rabbits, however, housing NZW bucks in the open system during hot period alleviated heat stress and improved their performance. Whereas, the performance of BB rabbits housed in open or semi-closed systems during hot period were nearly similar in most of parameters studied. These may be due to that $\mathrm{BB}$ rabbit bucks are more resistance to heat stress during hot period compared to NZW rabbits (Khalil, 2002).

Table 3. Thermoregulatory and hematological responses of rabbits as affected by interaction among climatic condition, housing system and breed

\begin{tabular}{|c|c|c|c|c|}
\hline \multirow{2}{*}{ Interactions } & \multicolumn{2}{|c|}{ Thermoregulatory response } & \multicolumn{2}{|c|}{ Hematological response } \\
\hline & $\mathrm{RT}\left({ }^{\circ} \mathrm{C}\right)$ & RR & Ht (\%) & $\mathrm{Hb}(\mathrm{g} / \mathrm{dl})$ \\
\hline Hot-Semi closed-NZW & $41.72^{\mathrm{a}} \pm 0.19$ & $169.3^{\mathrm{a}} \pm 3.8$ & $30.74^{\mathrm{e}} \pm 0.63$ & $9.95^{\mathrm{c}} \pm 0.25$ \\
\hline Hot-Semi closed-BB & $40.56^{\mathrm{b}} \pm 0.22$ & $132.4^{\mathrm{b}} \pm 4.1$ & $32.40^{\mathrm{de}} \pm 0.69$ & $10.68^{\mathrm{c}} \pm 0.27$ \\
\hline Mild-Semi closed-NZW & $40.12^{b c} \pm 0.19$ & $115.5^{\mathrm{c}} \pm 3.8$ & $37.94^{b} \pm 0.63$ & $12.99^{\mathrm{a}} \pm 0.25$ \\
\hline Mild-Semi closed-BB & $39.35^{\mathrm{d}} \pm 0.22$ & $102.3^{\mathrm{d}} \pm 4.1$ & $38.57^{\mathrm{ab}} \pm 0.69$ & $12.85^{\mathrm{a}} \pm 0.27$ \\
\hline Hot-Open-NZW & $41.22^{\mathrm{a}} \pm 0.19$ & $140.2^{\mathrm{b}} \pm 3.8$ & $33.30^{\mathrm{cd}} \pm 0.63$ & $11.58^{\mathrm{b}} \pm 0.25$ \\
\hline Hot-Open-BB & $40.30^{b c} \pm 0.22$ & $116.4^{c} \pm 4.1$ & $34.71^{\mathrm{c}} \pm 0.69$ & $11.95^{\mathrm{b}} \pm 0.27$ \\
\hline Mild-Open-NZW & $39.70^{\mathrm{cd}} \pm 0.19$ & $97.8^{\mathrm{d}} \pm 3.8$ & $40.24^{\mathrm{a}} \pm 0.63$ & $13.26^{\mathrm{a}} \pm 0.25$ \\
\hline Mild-Open-BB & $39.12^{\mathrm{d}} \pm 0.22$ & $94.4^{\mathrm{d}} \pm 4.1$ & $39.74^{\mathrm{ab}} \pm 0.69$ & $13.12^{\mathrm{a}} \pm 0.27$ \\
\hline Climate $\mathrm{x}$ Housing & NS & NS & NS & $* *$ \\
\hline Housing $\times$ Breed & NS & * & NS & NS \\
\hline Climate $\mathrm{x}$ Breed & NS & $* *$ & NS & $*$ \\
\hline Climate $\mathrm{x}$ Housing $\mathrm{x}$ Breed & ** & NS & NS & NS \\
\hline
\end{tabular}

${ }^{\mathrm{a}, \mathrm{b}}$ Values with different superscripts in the same column, differ significantly $(\mathrm{P}<0.05)$.

${ }^{* * *} \mathrm{P}<0.001,{ }^{* *} \mathrm{P}<0.01,{ }^{*} \mathrm{P}<0.05$ and $\mathrm{NS}=$ not significant.

Table 4. Semen characteristics of rabbits as affected by interaction among climatic condition, housing system and breed

\begin{tabular}{|c|c|c|c|c|c|}
\hline Interactions & $\begin{array}{c}\text { Ejaculate } \\
\text { volume } \\
(\mathrm{ml})\end{array}$ & $\begin{array}{c}\text { Sperm } \\
\text { concentration } \\
(\mathbf{x 1 0} / \mathrm{ml}) \\
\end{array}$ & $\begin{array}{c}\text { Sperm } \\
\text { motility } \\
(\%) \\
\end{array}$ & $\begin{array}{l}\text { Dead } \\
\text { sperm } \\
(\%) \\
\end{array}$ & $\begin{array}{c}\text { Sperm } \\
\text { abnormalities } \\
(\%) \\
\end{array}$ \\
\hline VZW & $0.63^{\mathrm{cd}} \pm 0.01$ & $267.5^{\mathrm{e}} \pm 8.2$ & $55.0^{f} \pm 0.85$ & $37.5^{\mathrm{a}} \pm 0.7$ & $31.5^{\mathrm{a}} \pm 0.9$ \\
\hline Hot-Semi closed-BB & $0.52^{\mathrm{f}} \pm 0.02$ & $308.7^{\mathrm{cd}} \pm 9.0$ & $61.2^{\mathrm{e}} \pm 0.93$ & $27.4^{\mathrm{b}} \pm 0.8$ & $22.1^{\mathrm{c}} \pm 1.0$ \\
\hline Mild-Semi closed-NZW & $0.78^{\mathrm{a}} \pm 0.01$ & $314.4^{\mathrm{cd}} \pm 8.2$ & $84.8^{\mathrm{a}} \pm 0.85$ & $16.6^{\mathrm{e}} \pm 0.7$ & $15.9^{\mathrm{ef}} \pm 0.9$ \\
\hline Mild-Semi closed-BB & $0.59^{\mathrm{de}_{\mathrm{e}}} \pm 0.02$ & $328.4^{\mathrm{bc}} \pm 9.0$ & $75.3^{c} \pm 0.93$ & $22.9^{c} \pm 0.8$ & $16.7^{\mathrm{de}} \pm 1.0$ \\
\hline Hot-Open-NZW & $0.70^{\mathrm{b}} \pm 0.01$ & $292.8^{\mathrm{d}} \pm 8.2$ & $64.6^{\mathrm{d}} \pm 0.85$ & $28.4^{b} \pm 0.7$ & $26.7^{\mathrm{b}} \pm 0.9$ \\
\hline Hot- & $0.54^{\mathrm{ef}_{ \pm}} \pm 0.02$ & $343.7^{\mathrm{b}} \pm 9.0$ & $64.8^{\mathrm{d}} \pm 0.93$ & $20.4^{\mathrm{d}} \pm 0.8$ & $18.9^{\mathrm{d}} \pm 1.0$ \\
\hline NZW & $0.65^{\mathrm{bc}} \pm 0.01$ & $331.5^{\mathrm{bc}} \pm 8.2$ & $80.7^{b} \pm 0.85$ & $15.5^{\mathrm{e}} \pm 0.7$ & $13.3^{\mathrm{f}} \pm 0.9$ \\
\hline Mild-Open-BB & $0.56^{\mathrm{ef}} \pm 0.02$ & $374.2^{\mathrm{a}} \pm 9.0$ & $83.4^{\mathrm{a}} \pm 0.93$ & $15.4^{\mathrm{e}} \pm 0.8$ & $18.9^{\mathrm{d}} \pm 1.0$ \\
\hline Cli & $* * *$ & NG & $* * *$ & $* * *$ & $* *$ \\
\hline Hou & NS & & $*$ & * & * \\
\hline Climate*Breed & NS & & $* * *$ & $* * *$ & $* * *$ \\
\hline Climate*Housing ${ }^{*}$ Breed & ** & $* * *$ & $* * *$ & $* * *$ & $* *$ \\
\hline
\end{tabular}

${ }^{\mathrm{a}, \mathrm{b}}$ Values with different superscripts in the same column, differ significantly $(\mathrm{P}<0.05)$.

${ }^{* * *} \mathrm{P}<0.001,{ }^{* *} \mathrm{P}<0.01,{ }^{*} \mathrm{P}<0.05$ and $\mathrm{NS}=$ not significant. 
Table 5. Testosterone hormone concentrations, reaction time, fertilizing ability of rabbits and litter size at birth as affected by interaction among climatic condition, housing system and breed

\begin{tabular}{|c|c|c|c|c|}
\hline Interactions & $\begin{array}{c}\text { Testosterone } \\
\text { concentrations } \\
(\mathrm{ng} / \mathrm{ml})\end{array}$ & $\begin{array}{l}\text { Reaction } \\
\text { time } \\
\text { (Second) }\end{array}$ & $\begin{array}{c}\text { Fertilizing } \\
\text { ability } \\
(\%)\end{array}$ & $\begin{array}{c}\text { Litter size } \\
\text { at } \\
\text { birth }\end{array}$ \\
\hline Hot-Semi-closed-NZW & $1.84^{\mathrm{e}} \pm 0.10$ & $39.50^{\mathrm{a}} \pm 0.87$ & $37 / 71\left(52.11^{\mathrm{d}}\right)$ & $5.62^{\mathrm{c}} \pm 0.28$ \\
\hline Hot-Semi-closed-BB & $1.87^{\mathrm{de}} \pm 0.11$ & $27.32^{\mathrm{b}} \pm 0.95$ & $38 / 60\left(63.33^{c}\right)$ & $5.42^{c} \pm 0.27$ \\
\hline Mild-Semi-closed-NZW & $2.77^{\mathrm{a}} \pm 0.10$ & $22.33^{\text {cde }} \pm 0.87$ & $67 / 82\left(81.71^{\mathrm{a}}\right)$ & $7.40^{\mathrm{a}} \pm 0.21$ \\
\hline Mild-Semi-closed-BB & $2.14^{\text {cde }} \pm 0.11$ & $23.54^{\mathrm{cd}} \pm 0.95$ & $49 / 66\left(74.24^{\mathrm{ab}}\right)$ & $5.53^{\mathrm{c}} \pm 0.25$ \\
\hline Hot-Open-NZW & $2.18^{\mathrm{bcd}} \pm 0.10$ & $24.28^{\mathrm{c}} \pm 0.87$ & $45 / 68\left(66.18^{\mathrm{c}}\right)$ & $6.49^{\mathrm{b}} \pm 0.25$ \\
\hline Hot-Open-BB & $2.08^{\mathrm{cde}} \pm 0.11$ & $20.84^{\mathrm{def}} \pm 0.95$ & $41 / 62\left(66.13^{c}\right)$ & $5.34^{\mathrm{c}} \pm 0.26$ \\
\hline Mild-Open-NZW & $2.48^{\mathrm{b}} \pm 0.10$ & $18.42^{\mathrm{f}} \pm 0.87$ & $57 / 78\left(73.08^{\mathrm{b}}\right)$ & $7.26^{\mathrm{a}} \pm 0.22$ \\
\hline Mild-Open-BB & $2.34^{\mathrm{bc}} \pm 0.11$ & $20.56^{\mathrm{ef}_{ \pm}} \pm 0.95$ & $47 / 67\left(70.15^{\mathrm{bc}}\right)$ & $5.77^{\mathrm{c}} \pm 0.25$ \\
\hline Climate $\mathrm{x}$ Housing & * & $* * *$ & $* *$ & NS \\
\hline Housing $\mathrm{x}$ Breed & NS & $* * *$ & NS & NS \\
\hline Climate $\mathrm{x}$ Breed & $*$ & $* * *$ & $*$ & $* *$ \\
\hline Climate $\mathrm{x}$ Housing $\mathrm{x}$ Breed & $*$ & $* *$ & $* *$ & NS \\
\hline
\end{tabular}

These results are in accordance with the findings of García-Tomas et al. (2008 $\mathrm{a} \& \mathrm{~b})$ who reported that environmental, management, physiological and genetic factors can affect normal spermatogenesis as well as sperm function, thereby altering male fertility. Variation in the seminal characteristics is known to be affected by many factors (genetic strain, feeding, health status, rearing condition, season, age and collection frequency), thus contributing to the large variability in semen traits (Alvariño, 2000). Gad et al. (1995) also found that NZW rabbits showed many changes in blood $\mathrm{Hb}$ and $\mathrm{Ht}$ levels, with higher drop in summer than Baladi Red rabbits. These results proved the sutability of the open system during hot period for maintaining the climatic conditions nearly within the comfort zone for rabbits.

\section{CONCLUSIONS}

1. Raising NZW rabbits in semi-closed system under severe heat stress caused disturbance in the physiological background consequently bad performance than that of $\mathrm{BB}$ rabbits.

2. Referred to the thermal properties of housing system, open system was the most favorable housing during hot period in middle Egypt, which reduced the deleteriously effects resulted in stressful hot conditions and enhanced biological responses which improved reproductive and productive efficiency, whereas semi-closed system turned to be favorable during mild period.

\section{REFERENCES}

Abdel-Samee, A.M., M.R.M. Mousa and M.A. Abdel Ghaffar, 2005. Productivity and reproductivity of heat stressed rabbits as influenced by nutritional treatments under Sinai conditions. The $4^{\text {th }}$ Inter. Con. on Rabbit Prod. in Hot Clim., Sharm El-Sheikh, Egypt, 365-371. 
Al-Sobayil, K. and M.H. Khalil, 2002. Semen characteristics of bucks in crossbreeding project involving Saudi Gabali with V-Line rabbits in Saudi Arabian. $3^{\text {rd }}$ Sci. Conf on Rabb. Prod. in Hot Climates, 8 - 11 Octob; Hurghada, Egypt; $151-163$.

Alvariño, J.M.R., 2000. Reproductive performance of male rabbits. In Proc. $7^{\text {th }}$ World Rabbit Congress, July, Valencia, Spain, Vol. A, 13-35.

Ashour, G. and M.M. Shafie, 2002. Impacts of housing conditions on rabbits performance in Egypt. $3^{\text {rd }}$ Sci. Conf. Rabbit Prod. in Hot Climates, 8-11 October, Hurghada, Egypt, pp. 57-74.

Ashour, G., A.A. Sedki and K.H. El-Kholy, 2005. Efficiency of housing establishment for rabbits productivity. The $4^{\text {th }}$ Inter. Con. on Rabbit Prod. in Hot Clim., Sharm El-Sheikh, Egypt, 425-434.

Baumans, V., 2005. Environmental enrichment for laboratory rodents and rabbits: requirement of rodents, rabbits, and research. ILAR J., 46 (2):162-170.

Brun, J.M., M. Theau-Clement, J. Esparbié, J. Falières, G. Saleil and C. Larzul, 2006. Semen production in two rabbit lines divergently selected for 63-d body weight. Theriogenology, 66, 2165-2172.

Castellini, C., 2008. Semen production and management of rabbit bucks. $9^{\text {th }}$ World Rabbit Congress - June 10-13, Verona, Italy: 265-278.

Duncan, D.B., 1955. Multiple range and multiple F. test. Biometrics, 11: 1-42.

El-Bashary, S.M., M.A. Bayoumy and A.A. Azamel, 2005. Semen characteristics of New Zealand white rabbit under different housing systems. $3^{\text {rd }}$ Sci Conf. Physiological response to environmental pollution. Society of Physiological Sci. and their Application, Ras Sedr, Egypt, 137-150.

EL-Kholy, Kh., 2003. Amelioration of heat stress on rabbits. Ph.D. Anim. Prod. Dep. Fac. Agric. Cairo Uni. Egypt.

El-Sherry, M.I., M.A. El-Naggar and S.M. Nassar, 1980. Experimental study of summer stress in rabbits: 2. The quantitive pathogenesis permatogenic cell cycle in rabbit. Assuiut Veterinary Medicine Journal, 7 (B/14):17-31.

El-Sobhy, H.E., 2000. Physiological responses and histochemical changes of some endocrine glands of NZW rabbit bucks exposed to $34^{\circ} \mathrm{C}$. Egyptian J. Rabbit Sci., 10: $19-41$.

Gad, H.M., G. Ashour and A.M. Saeed, 1995. Adaptive and reproductive performance of rabbits. 1. Response to seasonal conditions. Egyptian Journal of Animal Production, 32 (1): 63-75.

Garcia, M., M. Piles, J. Sanchez, O. Rafel, J. Ramon and M. Piles, 2006. Heterosis and maternal genetic effects on semen quality traits of rabbits. Livest. Sci., 104, 233-243.

Garcia-Tomás, M., M. Piles, J. Sánchez and T. Mitjavila, 2008a. Line and birth season effects on oxidative stress parameters in testis of maturing rabbits. $9^{\text {th }}$ World Rabbit Congress-June 10-13, Verona, Italy:353-358.

García-Tomás, M., J. Sánchez, O. Rafel, J. Ramon and M. Piles, 2007. Post-natal sexual developement of testis and epididymis in the rabbit: growth and maturity patterns of macroscopic and microscopic markers. Theriogenology (in press).

García-Tomás, M., L. Tusell, M. López-Béjar, J. Ramon, O. Rafel, M. Piles, 2008b. Influence of environmental temperature and relative humidity on quantitative and qualitative semen traits of rabbits. $9^{\text {th }}$ World Rabbit Congress-June 10-13, Verona, Italy: 359-364. 
Hammond, J., J.C. Bowman and J.J. Robinson, 1983. Hammond's Farm Animals. Fifth ed. Buther \& Tanner Ltd, Great Britain.

Hoy, St., 2005. Housing requirements for breeding rabbits from the viewpoint of welfare, behaviour and hygiene. The $4^{\text {th }}$ Inter. Con. on Rabbit Prod. in Hot Clim., Sharm El-Sheikh, Egypt,9 -13.

Hoy, St., 2008. Guidelines for minimum standards on rabbit housing in Germany. $9^{\text {th }}$ World Rabbit Congress-June 10-13, Verona, Italy: 1183-1187.

Ibrahim, H., M.I. Abd El-Rahim and M.N. El-Gaafary, 2005. Effect of housing system on rabbits performance, under hot climatic conditions. The $4^{\text {th }}$ Inter. Con. on Rabbit Prod. in Hot Clim., Sharm El-Sheikh, Egypt, 383-391.

Jegou, B., D.M. Laws and D.E. Kretser, 1984. Changes in testicular function induced by short term exposure of the germ cells, sertoli cells and leydig cells. Int. J. Andr., 7:244.

Khalil, M.H., 2002. Rabbit genetic resources in Mediterranean countries. Option Méditerranéennes, serie B: No. 38: 39-50.

Lebas, F., P. Coudert, H.De. Rochambeau and R.G. Thébault, 1997. The Rabbit Husbandry, Health and Production. Food and Agriculture Organization of the United Nations, FAO, Rome, Italy.

Marai, I.F.M., A.A.M Habeeb and A.E. Gad, 2002. Rabbits productive, reproductive and physiological performance traits as affected by heat stress: a review. Livestock Production Science, 78 (2): 71-90.

Marai, I.F.M., A.A.M Habeeb and A.E. Gad, 2004. Growth performance traits and the physiological background of young doe rabbits as affected by climatic conditions and lighting regime, under sub-tropical conditions of Egypt. $8^{\text {th }}$ World Rabbit Congress, September 7-10, Pueblo, Mexico :288-297.

Meshreky, Samia Z., 2007. Effect of two different housing systems on the performance of New Zealand white rabbits under hot and mild climatic conditions of middle Egypt. Journal of Egyptian Poultry Science, 27 (III): 851-874.

Meshreky, Samia Z. and A. Farid, 2007. Reproductive performance of New Zealand White and Baladi black doe rabbits raised in two different housing systems under hot and mild climatic conditions of middle Egypt. The $5^{\text {th }}$ Inter. Con.on Rabbit Prod. in Hot Clim., Hurghada, Egypt, 469 - 484.

Meshreky, Samia Z., Mervat M. Arafa and M.A. Abo Warda, 2005. Evaluation of male capabilities in V-line, Baladi Red rabbits and their cross under the Egyptian environmental conditions. Proc. $2^{\text {nd }}$ Conf. Anim. Prod. Res. Inst., Sakha, 27-29 Sep.:681-693.

Mocé, E., J.S. Vicente, R. Lavara, M.P. Viudes De Castro, M. Lopez and G. Bolet, 2005. Characteristics of fresh semen from eight rabbit breeds. Reprod. Domest. Anim., 40: 388-398.

Ogunjimi, L.A.O., 2007. Optimization of thermal comfort in a naturally ventilated livestock building. Ph. D. Thesis; Agricultural Engineering Department, Obafemi Awolowo University, Ile-Ife, Osun State, Nigeria.

Ogunjimi, L.A.O., S.O. Oseni and F. Lasisi, 2008. Influence of temperature-humidity interaction on heat and moisture production in rabbit. $9^{\text {th }}$ World Rabbit CongressJune 10-13, Verona, Italy: 1579-1583.

Pascual, J.J., C. Garcia, E. Martinez, E. Moce and J.S. Vicente, 2004. Rearing management of rabbit males selected by high growth: the effect of diet and season on semen characteristics. Reprod Nutr Dev., 44 (1): 49-63. 
Piles, M., Ll. Tusell, M. García-Tomás, M. Baselga, I. García-Ispierto, O. Rafel, J. Ramon and M. López-Bejar, 2008. Genotype x sperm dosage interaction on reproductive performance after artificial insemination. 1. Male fertility. $9^{\text {th }}$ World Rabbit Congress-June 10-13, Verona, Italy: 221-225.

Pla, M., 1998. Carcass and meat quality of growing rabbits under high ambient temperature using high fat diets. In the Proceeding of $2^{\text {nd }}$ International Conference on Rabbit Production in Hot Climate, (7-9 Sep.) Adana, Turkey.

Rathore, A.K., 1970. High temperature exposure of male rabbits. Indian Veterinary Journal, 47: 837-840.

Roca, J., S. Martínez, J. Orengo, I. Parrilla, J.M. Vázquez, E.A. Martínez, 2005. Influence of constant long days on ejaculate parameters of rabbits reared under natural environment conditions of Mediterranean area. Livestock Production Science, 94, 169-177.

Rodriguez, De Lara R., A. Herrera, M. Lopez, R. Rangel, V. Mariscal, A. Martinez and J.G Garcia, 2007. Influence of supplemental dietary sprouted wheat on reproduction in artificially inseminated doe rabbits. Anim Rep. Sci., 99:145-155.

Rodríguez, De Lara R., M. Fallas-López, R. Rangel-Santos, V. Mariscal-Aguayo, P.A. Martínez-Hernández, J.G. García Muñiz, 2008. Influence of doe exposure and season on reaction time and semen quality of male rabbits. $9^{\text {th }}$ World Rabbit Congress, June 10-13, Verona, Italy: 443-447.

Saacke, R.G., J.C. Dalton, S. Nadir, R.L. Nebel and J.H. Bame, 2000. Relationship of seminal traits and insemination time to fertilization rate and embryo quality. Anim. Reprod. Sci., (60-61): 663-677.

SAS $^{\circledR}, 1996$. User's Guide: Statistics, Version 6.12 Edition. SAS inst. Inc., Cary, NC, USA.

Tharwat, E.E., Y. El-Hommsany, H.A. Al-Shanti, A.F. Hussain and A.M. El Sherbiny, 2004. Seasonal variation in semen quality and fertility of domesticated Sinai Gabali rabbit bucks. Egyptian J. Rabbit Sci., 14 (1): 29-38.

Theau-Clément, M., N. Michel, J. Esparbié, G. Bolet, 1995. Effect of artificial photoperiods on sexual behaviour and sperm output in the rabbit. Anim. Sci., 60, 143-149.

Verga, M., F. Luzi and C. Carenzi, 2007. Effect of husbandary and management system on physiological and behaviour farmed and laboratory rabbits. Horm Behav. 4; [Epub ahead of print].

Villalobos, O., O. Guillén and J. García, 2008. Effect of cage density on performance of fattening rabbits under heat stress. $9^{\text {th }}$ World Rabbit Congress - June 10-13, Verona, Italy: 1631-1635.

Viudes, De Castro M.P., F. Marco-Jiménez, J.S. Vicente, E. Navarro, R. Lavara and E. Mocé, 2004. Sperm kinetic parameters and differences in seminal plasma composition among two rabbit lines. In Proc. $8^{\text {th }}$ Annual Conf. European Society of Domestic Animal Reproduction. Reproduction in Domestic Animals 394. 266 Abstract (P13). Warsaw Agricultural University, Poland. 


\section{تأثير الظروف الجوية، نظام الأيواء و السلاله على أداء ذكور الأرانب الناضجة المرباة فى \\ مصر الوسطى}

سامية زكريا مشرقي، صلاح ذكى جاد الله، محمد أنور أبو وردة

معطج بحوث الإنتاج الحيوانس، مركز البحوث النراعية، وزلرة النزاعة

أستخدم فى هذه الدراسة ؟ ؛ ذكر أرنب نيوزيلاندى أبيض و بلدى أسود عمر 1 شهور على فترتين.

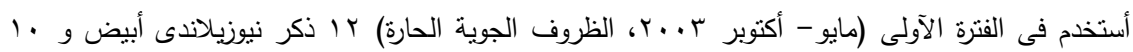

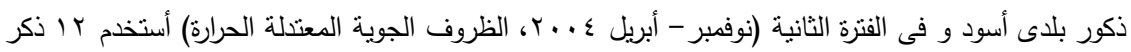
نيوزيلاندى أبيض و • ا ذ ذكور بلدى أسود. فى كلتا الفترتين, قسمت الذكور من كل سلاله الى مجموعتين

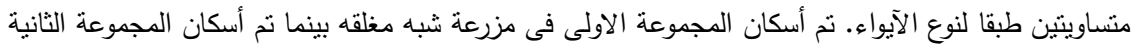

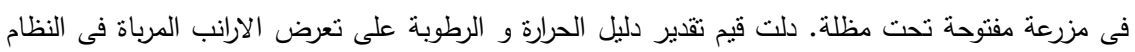

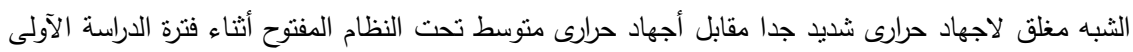
و غياب الأجهاد الحرارى خلال فترة الدراسة الثانية.

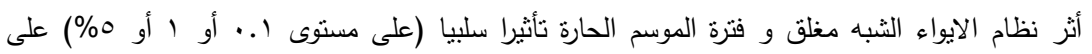

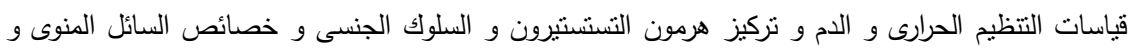

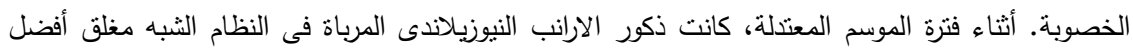

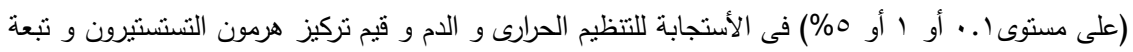

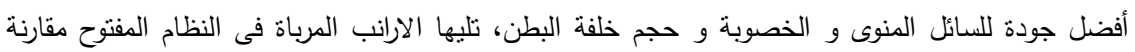

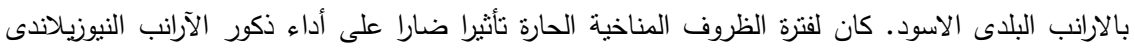

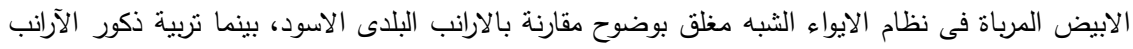

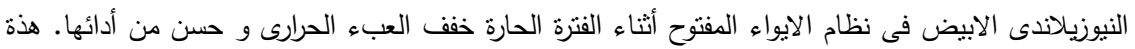

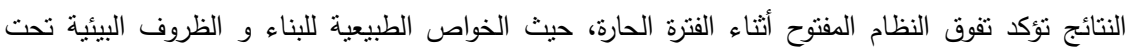
المظلة أنعكست بوضوح على أداء ذكور الأرانب والتى تحققت عن طريق الإنتجابات البيولوجية و التى تعتبر من الادلة الدقيقة على نوافق الحيوان مع البيئه المحيطه به. 